\title{
What I did on my holidays
}

Travel broadens the mind.

\section{Ian Stewart}

At first I was disappointed when Dad said we weren't going to Blackpool this year. Yes, I know - like Mum told him - it's crowded and noisy and the entertainment's a bit naff, but there's a lot for the kids (that's me and Treec), and we've been there for the past ten years so we know it and we feel comfortable.

"We ought to be more adventurous," Dad said.

"The Wilkinsons have been to Majorca," said Mum.

"A bit more adventurous than that," Dad said.

"Like what?" I butted in. I'm Gemstone-Sally Worthington, aged twelve, and this is my blog.

"Eatyworld," Dad said. Well, it's really 'E-T World', which is the bloids' name for Gliese-581c, but everyone pronounces it that way.

"We can't afford Eatyworld," Mum said.

"Special introductory deal," Dad said. “They've built a new themeplex beside that big lake where the shark-things live."

"Selachinoids," said Treecreeper-Darren, my step-half-brother. Treec does that kind of thing in his avatar classes. He's a pain.

"It's the wormgate tickets we can't afford," Mum objected, "not the entry to the themeplex. You know how much extraterrestrial costs! Why, even the Yeghiazarians decided against it." Pagoda-Sue Yeghiazarian is almost my friend, she's eleven and three quarters.

"Not if we go via Hanoi," Dad said. "Speedijump have opened up a new budget wormgate. It costs less than the local gate to Blackpool." Mum gave him that quizzical look of hers. "Of course there's the return trip to Hanoi as well, but we still save a lot."

So it was decided. Mum started listing the things we ought to pack, I downloaded a blogplate and uploaded the resultant blog so all my friends would know we were going, especially Pagoda-Sue Yeghiazarian, and Treec found some really gross virts about aliens that we both watched until Mum found out and banned him from the site.

By the time we set off we were really looking forward to Eatyworld. It's got a gigantomorph reserve, and a world-

girdling forest with millions of pandamoniums. Apparently the Eaties themselves are a bit weird, but they're allowed to be because they live there. I can't tell you how excited we all were!

Well, what Speedijump doesn't tell you, Mum complained at length on our arrival in Hanoi, is that actually their gate to Eatyworld is on the outskirts of Louangphrabang. So there's a train ride (yes, a genuine old-fashioned train - there were people riding on

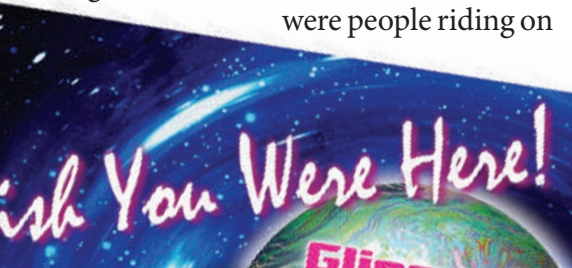

Most of the time we stayed in the themeplex. You don't actually see any Eaties, because they're not like real aliens with ten legs and six eyes and either scary or cuddly or just sort of grey versions of us. They're difficult to describe - a bit like colonies of vertical slugs glued together and they're slimy and they smell bad. But we smell even worse to them, so they stay well away from the tourist compound. The themeplex has people in alien suits to show you where the rides are, anyway, so you get the genuine extraterrestrial experience.

We did visit the gigantomorph reserve, but new health and safety rules meant that we had to stay at least two kilometres away from the creatures. Apparently some kid had jumped off the hovertrax and a gigantomorph had sat on him and licked up the mess. The kid was insured but the gigantomorph wasn't, and it died from blood poisoning. Dad bought some binoculars so we could see enough of the beasts to appreciate how impressive they would have been close up.

the roof but we went first class, which meant we had seats), which costs extra. As does the food, the drink, the ticket for the toilet queue, border tax from 'Nam into Laos, baggage surcharge and carbon debit.

Too late, Treec discovered that there used to be a virtsite warning potential customers, but it was taken down by a bot battalion. Still, we were going to Eatyworld! A little extra expense and discomfort would be a small price to pay, Dad said.

The actual wormgate transit was over before we'd realized. You join a queue shuffling down a long corridor, and just after the fifth security check there's a red line on the floor and a sign that says 'Welcome to Gliese-581c, please mind the gravitational discontinuity, this courtesy holo sponsored by Lonely Star Insurance'.

The hotel was pretty good. The lake was frozen at this time of year, and the sharkthings were hibernating. But the room did have a holovirt projector exactly like the one we've got in Finchley. So Treec and I watched holos of selachinoid packs, showing what we would have seen if we'd come during high season - a two-week period when the lake isn't covered in ice. Of course the special offer isn't available then, Dad said.
The world-girdling forest, it turned out, had been opened up to sustainable logging, and only a few patches of the former Planetary Parks were still standing. But that wasn't quite the same, especially as the remaining pandamoniums had all died from a virus brought in by a tourist from Pittsburgh. So we mostly stayed in the themeplex.

The trip back was a breeze until we got to Louangphrabang, only to find that the railway to Hanoi was closed because terrorists had blown up a bridge. So we had to go standby via Kamchatka and Tierra del Fuego, while our bags went to Tokyo and then disappeared. How can you lose four bags in an enclosed corridor? I was upset because I'd packed my souvenirs in the checked baggage, but Mum said they were all made in Taiwan and transported to Eatyworld anyway. So she'll replace the set of plastic gigantomorphs and we'll forget the other stuff.

Treec and I want to go back to Eatyworld next year. But Mum and Dad say we're going to Blackpool.

lan Stewart is co-author of Wheelers, Heaven and the Science of Discworld trilogy. When not writing books, he does serious mathematics at the University of Warwick, UK. 